\title{
The unemployment effects of fiscal policy: recent evidence from Greece
}

Athanasios O Tagkalakis

Correspondence: atagkalakis@ bankofgreece.gr

Economic Research Department, Bank of Greece, 21 El. Venizelos Av., 10250, Athens, Greece

\section{Springer}

\begin{abstract}
This paper investigates the unemployment effects of fiscal policy in Greece based on the SVAR methodology. We find evidence that the unemployment and growth effects can be quite sizeable in case of cuts in government purchases and in particular government consumption and to a lesser extent government investment. Tax hikes reduce output and increase unemployment, in particular those leading to higher implicit direct and indirect tax rates. The impact effects of fiscal policy on output and unemployment are more sizeable when considering recent year developments. Both output and unemployment respond in a more persistent manner, compared to pre-crisis years.

JEL Codes: $\mathrm{E} 6, \mathrm{H} 6, \mathrm{H} 3$

Keywords: Government spending; Implicit tax rates; Unemployment; Output
\end{abstract}

\section{Introduction}

On account of severe sovereign debt financing problems Greece has been receiving since May 2010 international financial assistance from the EU and the International Monetary Fund (IMF, 2010). In the context of the EU-IMF financing agreement Greek authorities implement the Economic Adjustment Programme (EAP). Progress up till now has been mixed with substantial improvement in the fiscal consolidation effort and labor market reforms and significant delays in the implementation of product market reforms and privatizations (IMF, 2013a) ${ }^{1}$. Unfortunately, the progress in fiscal adjustment has come at a cost of a dramatic and continuing output contraction, as well as rising unemployment.

According to the first $\mathrm{EAP}^{2}$ a recovery was projected as early as 2012. However, according to the latest European Commission forecasts (European Commission 2013a) the path has been quite different so far, i.e., from a mild recession of -0.2 in 2008 Greece went into a much deeper recession in the next years, i.e., $-3.1 \%$ in $2009,-4.9 \%$ in $2010,-7.1 \%$ in $2011,-6.4 \%$ in 2012 . Output is now expected to contract at a slower pace in 2013 , i.e., $-4.2 \%$; a mild recovery of $0.6 \%$ is postponed until 2014 . Similarly, the unemployment rate ended up much bigger than initially expected ${ }^{3}$. It was $17.7 \%$ in 2011, 24.3\% in 2012 and is now expected to reach $27 \%$ in 2013, before declining to 26\% in 2014 (European Commission 2013a). According to Elstat (2013) the unemployment rate reached 27.6\% in May 2013, compared to $23.8 \%$ in May 2012, while youth unemployment has increased from about 25,1\% in May 2009 to about 64.9\% in May

(C) 2013 Tagkalakis; licensee Springer. This is an Open Access article distributed under the terms of the Creative Commons Attribution License (http://creativecommons.org/licenses/by/2.0), which permits unrestricted use, distribution, and reproduction in any medium, provided the original work is properly cited. 
2013. These unemployment developments challenge social cohesion, putting at risk the public support to the on-going fiscal consolidation effort.

According to earlier European Commission and IMF analysis the strong output contraction and the dramatic increase in unemployment has been attributed to reform fatigue and delays in the implementation of structural reforms, which impair the internal adjustment process (see e.g. European Commission 2012; IMF 2012a). However, quite recently the IMF showed that fiscal multipliers might have been underestimated (by a factor of 2-3) in the recent years in a number of countries implying that fiscal consolidation efforts had deeper recessionary effects than anticipated (see IMF, 2012b; Blanchard and Leigh, 2013).

Driven by these development, using a quarterly dataset, this paper investigates the growth and unemployment effects of fiscal policy changes in Greece in the period 2000-2012 . This analysis is quite topical because policy makers need to have full knowledge of the likely unemployment effects of fiscal consolidation and the social risks that this entails. The he analysis builds on the Blanchard and Perotti (2002) SVAR methodology, as well as on Monacelli et al. (2010) and Pappa (2009) in examining the growth and unemployment effects of exogenous fiscal policy changes.

According to our findings, an increase (cut) in government purchases and its subcomponents, i.e., government consumption, the government wage bill and government investment increase (lower) output and reduce (raise) unemployment and the unemployment rate. One year after a negative government purchase shock the unemployment rate increases by about 0.74 p.p. Whereas, two years after the shock the cumulative unemployment rate increase reaches about 0.91 p.p. The unemployment rate effects are double if we assume that the unemployment rate stabilizes around its 2012 level (24.3\%). It is primarily government consumption and in particular the wage bill component that drives the output and unemployment responses. Turning to tax variables, increases in the tax burden, and in its subcomponents, such as direct and indirect tax revenues reduce output growth and increase unemployment, but the unemployment response is short lived. Implicit direct and indirect tax rate hikes reduce output growth and increase unemployment rate in a quite pronounced and persistent manner. Both output and unemployment rate responses are more sizeable on impact following government purchases and implicit tax rates shocks compared to the pre-EAP period. In addition, their response profile is more pronounced and persistent compared to the pre-EAP sample (but only in outer years in case of government purchases).

The remainder of the paper is organised as follows. The next section reviews the relevant literature on the labor market effects of fiscal policy. Section 3 presents some data information and discusses in more detail the SVAR econometric methodology. In Section 4 we present the main empirical findings. Section 5 includes a brief summary of the results and concluding remarks. An Appendix provides additional information on data issues ${ }^{5}$.

\section{Relevant literature: labor market effects of fiscal policy changes}

The standard RBC model analyzing the effects of fiscal policy imply that a positive government spending shock in the present period that is to be matched by higher labor taxes in the current and future periods generates a wealth effect that decreases 
consumption and increases labor supply. Both the inter-temporal substitution effect (individuals prefer to supply more labor when labor taxes are low) and the intratemporal substitution effect (individuals prefer to supply more labor when the cost of work relative to leisure is low) reduce labor supply, while the inter-temporal effect decreases consumption. In this case, the impact effect on labor supply and real wages is ambiguous. If the elasticity of labor supply is relatively large, employment may decrease while real wages increase. The increase in government spending, reduces national savings and raises the real interest rate, which reduces investment, and in the medium term lowers the capital stock and thus lowers demand for labor. The exact response profile of employment, real wages and output in the medium term will depend on the magnitude of the wealth effect relative to the substitution effect.

Introducing New Keynesian features in a standard RBC model, like price stickiness and monopolistic competition, implies that firms meet the higher demand for their products by increasing their labor demand on impact. This boosts employment and real wages. Overall, the implications for employment and real wages, consumption and consequently output and investment will depend on the strength of the intertemporal and intratemporal substitution effects relative to the wealth effect and the severity of price rigidities, as well as the persistence of the government spending shock and the timing of taxation.

Bassanini and Duval (2006a,b) focusing on OECD countries find that higher labor taxes (whether including consumption taxes or not) raise unemployment ${ }^{6}$. Studies for the US such as Fatas and Mihov (2001), Burnside et al. (2004), Gali et al. (2007) Cavallo (2005) find positive effects on employment following a government spending shock. Monacelli et al. (2010) estimate the effects of fiscal policy on the labor market using US data. An increase in government spending of 1 percent of GDP generates output and unemployment multipliers, respectively, of about 1.2-1.5 percent (at one year and two year horizon, respectively) and -0.6 percentage points (at the peak). Hours and employment also rise significantly following a government spending shock, with a peak response of about 1.5 percent.

Several other studies have emphasized that researchers should differentiate the impact of the wage and the non wage component of government spending. Finn (1998), in an RBC model with competitive labor markets and lump-sum taxation, suggests that an increase in government employment can lead to lower private sector employment (if the wealth effect is small) and higher real wages, as well as lower private sector hours, output and investment. Lane and Perotti (2003) and Alesina et al. (2002) identify a cost or labor market channel of fiscal policy. An increase in government purchases, and in particular the wage bill component of government spending, increases the wages in the private sector, reducing firm profits, which leads to a decrease in employment and business investment in current and future periods. As a result, output, income and private consumption expenditure contract.

Pappa (2009), employing an RBC model, reports that an increase in government employment that leads through factor relocation to a reduction in private sector employment can increase output, consumption and investment and raise real wages if government employment is productive for the private sector. However, if private employment was unproductive output would have fallen. In the New Keynesian version of the model, where there is price stickiness, total employment may even fall and real 
wages and output do not increase as much as in the RBC version. Although increased government absorption increases demand, firms do not have to increase employment in response to the shock and they may actually decrease it.

Similarly, Cavallo (2005) finds that a government employment shock decreases private sector hours, output and investment. Ardagna (2007) adds Keynesian features in the labor market, i.e. the labor market is unionized, and finds that the increase in government wage bill raises the outside option of workers, leading to higher real wages in the private sector. Tagkalakis (2006) studying UK data suggest that a government spending shock leads to a negative response for private employment, with the effect being attributed to the wage bill component of government spending. Moreover Pappa (2009) examining the transmission of fiscal shock in the labor market using data for US States finds that shocks to government consumption and investment increase real wages and employment in the aggregate and at the state level, but shocks to government employment give mixed results, they increase employment in the aggregate, but they reduce it in $1 / 3$ of the US States considered ${ }^{7}$.

\section{Data information and SVAR methodology}

We use quarterly data from 2000 to 2012. In view of the small sample size we consider a parsimonious specification which is a variant of those used in Blanchard and Perotti (2002) and Monacelli et al. (2010).

In order to examine the effects of government spending shocks we consider the following 4 variable $\operatorname{SVAR}^{8}$ : the change in log of real government spending/purchases (which is the sum of government consumption and government investment), the change in the log of real net taxes (total current revenue excluding current transfers) ${ }^{9}$, the change in the log of real GDP, and the change in the log of the number of unemployed. Following Monacelli et al. (2010) the unemployment variables enters after real GDP. Variables are transformed in real terms using the GDP deflator ${ }^{10}$.

The (lagged value of the) debt to GDP ratio is included as an exogenous variable to capture the constraints imposed on fiscal policy by debt developments in line with Favero and Giavazzi (2007). The SVAR specification includes an intercept; the lag length is set to $1^{11}$. In addition we include a dummy variable called EAP, which takes value 1 from 2010 Q2 onwards and zero otherwise. EAP controls for two things: (1) the fact that Greece has been cut off from financial markets since the start of the EU-IMF finance programme, which in itself is a major structural change and (2) for the fact that numerous labor market reforms have been undertaken in the period of implementation of the Economic Adjustment Programme (EAP), see e.g. IMF (2013a).

The SVAR we estimate is of the form:

$$
X_{t}=A_{1} * X_{t-1}+A_{2} * X_{t-2}+C_{t}+B * D_{t-1}+u_{t}
$$

Where $X_{t}=[G, T, Y, U]$ is the vector of endogenous variables, $C_{t}$ contains the deterministic terms and $D_{t-1}$ is the debt to GDP ratio. $u_{t}$ are the VAR innovations. Building on the Blanchard and Perotti (2002) SVAR approach we identify the structural shocks to $G$ and $T$ by imposing on the matrices $A$ and $B$ that determine the 
mapping from the VAR innovations $u$ to the structural shocks $\varepsilon\left(A u_{t}=B \varepsilon_{t}\right)$ the following restrictions:

$$
\left[\begin{array}{llll}
1 & 0 & \alpha_{\mathrm{gy}} & \alpha_{\mathrm{gU}} \\
0 & 1 & \alpha_{\mathrm{ty}} & \alpha_{\mathrm{tU}} \\
\alpha_{31} & \alpha_{32} & 1 & 0 \\
\alpha_{41} & \alpha_{42} & \alpha_{43} & 1
\end{array}|| \begin{array}{l}
\mathrm{u}_{\mathrm{gt}} \\
\mathrm{u}_{\mathrm{tt}} \\
\mathrm{u}_{\mathrm{yt}} \\
\mathrm{u}_{\mathrm{Ut}}
\end{array}\left|=\left[\begin{array}{llll}
\beta_{11} & 0 & 0 & 0 \\
\beta_{21} & \beta_{22} & 0 & 0 \\
0 & 0 & \beta_{33} & 0 \\
0 & 0 & 0 & \beta_{44}
\end{array}\right]\right| \begin{array}{l}
\varepsilon_{\mathrm{gt}} \\
\varepsilon_{\mathrm{tt}} \\
\varepsilon_{\mathrm{yt}} \\
\varepsilon_{\mathrm{Ut}}
\end{array} \mid\right.
$$

Following Blanchard and Perotti (2002) we set $\alpha_{\mathrm{gy}}=\alpha_{\mathrm{gU}}=0$, whereas using information from the Girouard and Andre (2005) we set $\alpha_{\mathrm{ty}}=0.9^{12}$. We set $\alpha_{\mathrm{tU}}=-0.27$ using the information provided in Girouard and Andre (2005). In line with Blanchard and Perotti (2002) we set $\beta_{12}=0$ and estimate $\beta_{21}{ }^{13}$. The above specification is used to examine the effect of a government spending/purchases shock on output and unemployment. However, in order to examine the effect of the revenue component we include the tax burden (instead of the net tax variable). This is the sum of the following revenue categories: direct taxes, indirect taxes, social security contributions and capital taxes. This variable will better reflect the impact of the increased tax burden imposed on society on output and unemployment.

\subsection{Composition effects of fiscal policy}

In order to assess the output effects of individual government expenditure and revenue component we have re-estimated (1) considering:

a) 4 different 5 variables SVAR specifications, i.e., one for each individual spending component that we consider: government consumption, government investment, current government transfers (including social payments, i.e., pensions, inability benefits etc.) and compensation of employees (the government wage bill). In each case the government purchase variable is replaced by one of the abovementioned individual spending components and enters before the net tax variable. In addition, in order to control for possible correlation between the budgetary items we incorporate in the SVAR (after the net tax variable) the remaining government spending components, i.e., we consider a 5 variable SVAR. Hence, when the variable of interest is government consumption the third variable in the SVAR is government investment; when the variable of interest is government investment the third variable in the SVAR is government consumption, while in the case of government wage bill we add as third variable in the SVAR the difference between government purchases and government wage bill ${ }^{14}$. Whereas, when the variable of interest is current government transfers we include as second variable in the SVAR the tax burden and as third government purchases.

b) 2 different 5-variable SVAR specifications, i.e., one for direct taxes and one for indirect tax revenue. In each case one of the abovementioned individual revenue components enters in the SVAR after the government purchases. Furthermore, in order to control for changes in other tax revenue variables we incorporate in the SVAR (as a third variable) the remaining tax revenue components, i.e. we consider a 5 variable SVAR. When the variable of interest is direct taxes (indirect tax revenue) the third variable in the SVAR is current revenue minus direct taxes (current revenue minus indirect taxes). 
c) 2 additional SVAR specifications where the tax variable of interest is the implicit direct tax rate (implicit indirect tax rate) ${ }^{15}$. In this case the relevant expenditure variable is government purchases, while the third tax variable is current revenue minus direct taxes current revenue minus indirect taxes ${ }^{16}$.

In case of these 5-variable SVARs the following restrictions apply to the A and B matrices:

$$
\left[\begin{array}{lllll}
1 & 0 & 0 & \alpha_{\mathrm{gy}} & \alpha_{\mathrm{gU}} \\
0 & 1 & 0 & \alpha_{\mathrm{ty}} & \alpha_{\mathrm{tU}} \\
\alpha_{31} & \alpha_{32} & 1 & 0 & 0 \\
\alpha_{41} & \alpha_{42} & \alpha_{43} & 1 & 0 \\
\alpha_{51} & \alpha_{52} & \alpha_{53} & \alpha_{54} & 1
\end{array}|| \begin{array}{l}
\mathrm{u}_{\mathrm{gt}} \\
\mathrm{u}_{\mathrm{tt}} \\
\mathrm{u}_{\mathrm{rgt}} \\
\mathrm{u}_{\mathrm{yt}} \\
\mathrm{u}_{\mathrm{Ut}}
\end{array}|=| \begin{array}{lllll}
\beta_{11} & 0 & 0 & 0 & 0 \\
\beta_{21} & \beta_{22} & 0 & 0 & 0 \\
0 & 0 & \beta_{33} & 0 & 0 \\
0 & 0 & 0 & \beta_{44} & 0 \\
0 & 0 & 0 & 0 & \beta_{55}
\end{array}|| \begin{array}{l}
\varepsilon_{\mathrm{gt}} \\
\varepsilon_{\mathrm{tt}} \\
\varepsilon_{\mathrm{rgt}} \\
\varepsilon_{\mathrm{yt}} \\
\varepsilon_{\mathrm{Ut}}
\end{array} \mid\right.
$$

The government spending and revenue elasticity assumptions in (2) still hold in (3) in the case of the 5-variable SVAR specifications examining the output and unemployment effects of government consumption, government investment, and compensation of employees. In case of government transfers we assume that the output and unemployment elasticity assumptions with respect to the tax revenue variable still hold, however, we now assume that the output elasticity of government transfers is set to $\alpha_{\mathrm{gy}}=-0.17$ and the unemployment elasticity of government transfers is set to $\alpha_{\mathrm{gU}}=0.05$; i.e., we assume that government transfers respond to output and unemployment contemporaneously. In the case of the SVAR specifications examining the output effects of each individual revenue specification, the output elasticity of direct taxes is set to 1.40 and the output elasticity of indirect tax revenue is set to 1 based on the elasticities estimated by Girouard and Andre (2005). While the unemployment elasticity of indirect tax revenue is set to $\alpha_{\mathrm{tU}}=-0.30$ and the unemployment elasticity of direct taxes is set to $\alpha_{\mathrm{tU}}=-0.42^{17}$.

\section{Main findings}

The findings are presented in Figures 1, 2, 3, 4, 5, 6, 7, 8, 9 and 10. In Figures 1, 2, 3, 4 and 5 we consider the government expenditure components. In Figures 6, 7 and 8 we present the findings for tax revenue variables and in Figures 9 and 10 the impulse responses for the implicit tax rate SVARs. The solid red line in each figure represents the response profile of the variable of interest following a spending or revenue shock. The black dashed and round dot lines are the $68 \%$ and $90 \%$ confidence intervals, which have been calculated by bootstrapping the residuals (1000 bootstrap replications were performed).

An issue that requires particular attention relates to the possibility of structural breaks in sample. The most prominent event that occurred in the period under examination relates to the lack of market access in 2010 Q2 (on account of sovereign debt problems), which, subsequently led to the EU-IMF financing agreement for Greece. By incorporating two exogenous variables, the dummy variable EAP (that takes value 1 from 2010 Q2 onwards and zero otherwise) and the lagged debt ratio we do account for some of these developments. However, in order to gain more insights on the possibility of differential effects of fiscal policy pre- and post EAP implementation we repeat 


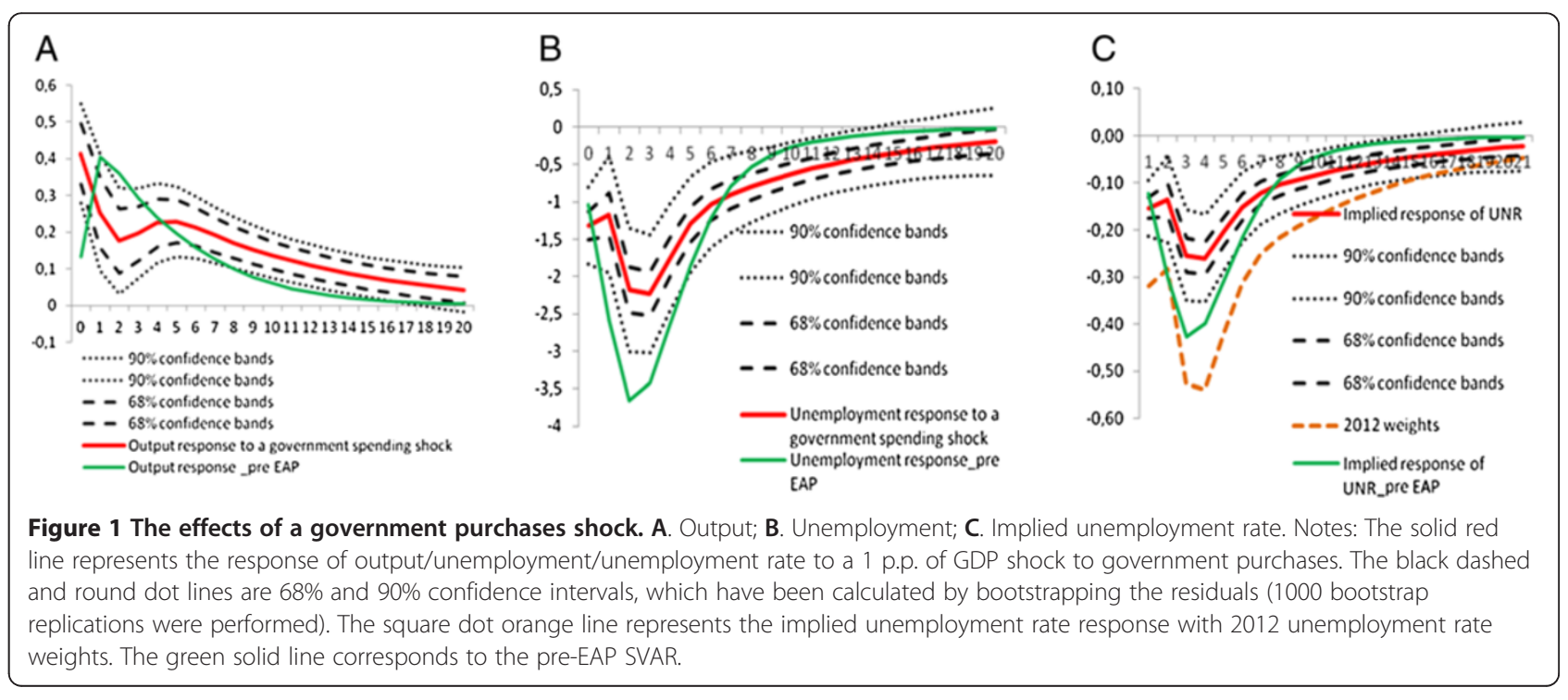




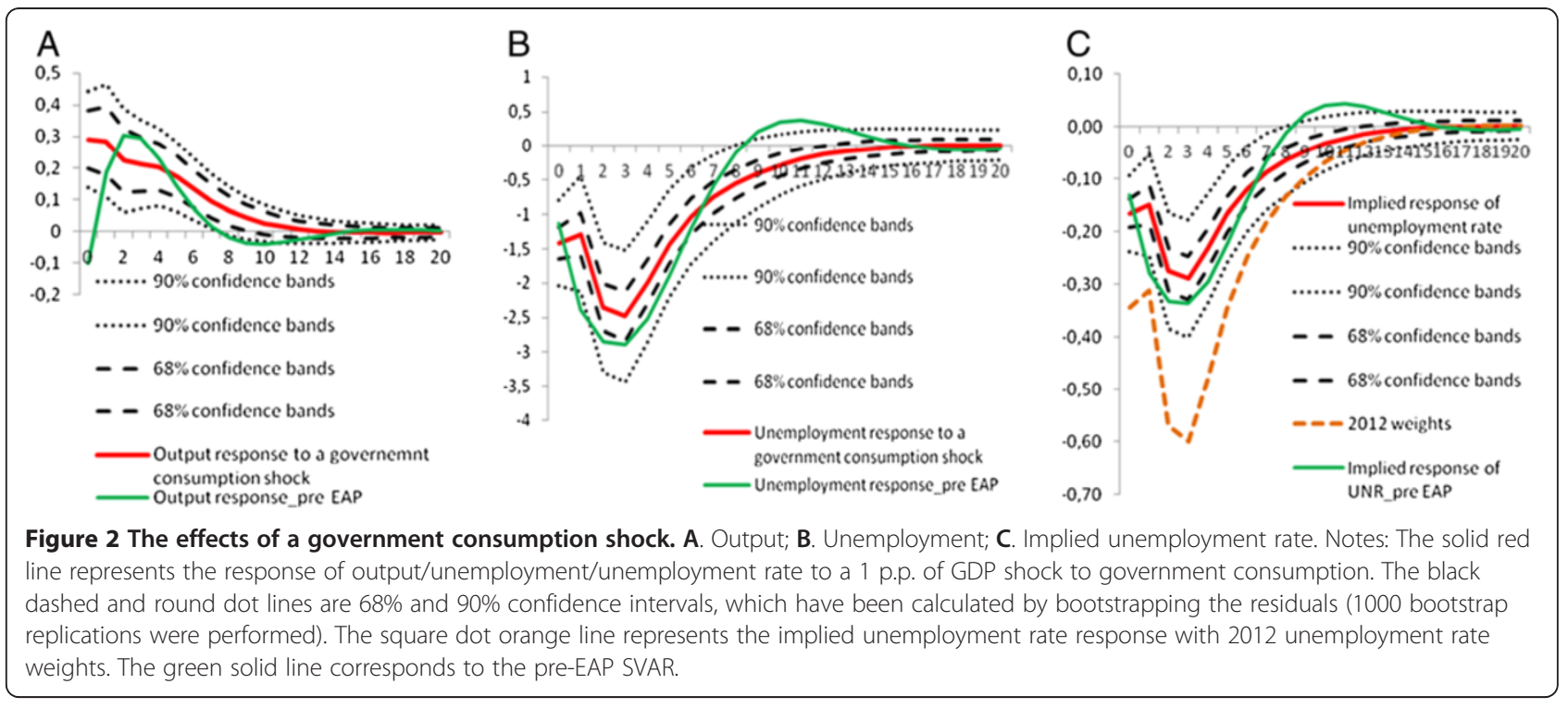




Figure 3 The effects of a government wage bill shock. A. Output; B. Unemployment; C. Implied unemployment rate. Notes: The solid red line
represents the response of output/unemployment/unemployment rate to a 1 p.p. Of GDP shock to government wage bill. The black dashed and
round dot lines are 68\% and 90\% confidence intervals, which have been calculated by bootstrapping the residuals (1000 bootstrap replications
were performed). The square dot orange line represents the implied unemployment rate response with 2012 unemployment rate weights. The
green solid line corresponds to the pre-EAP SVAR.




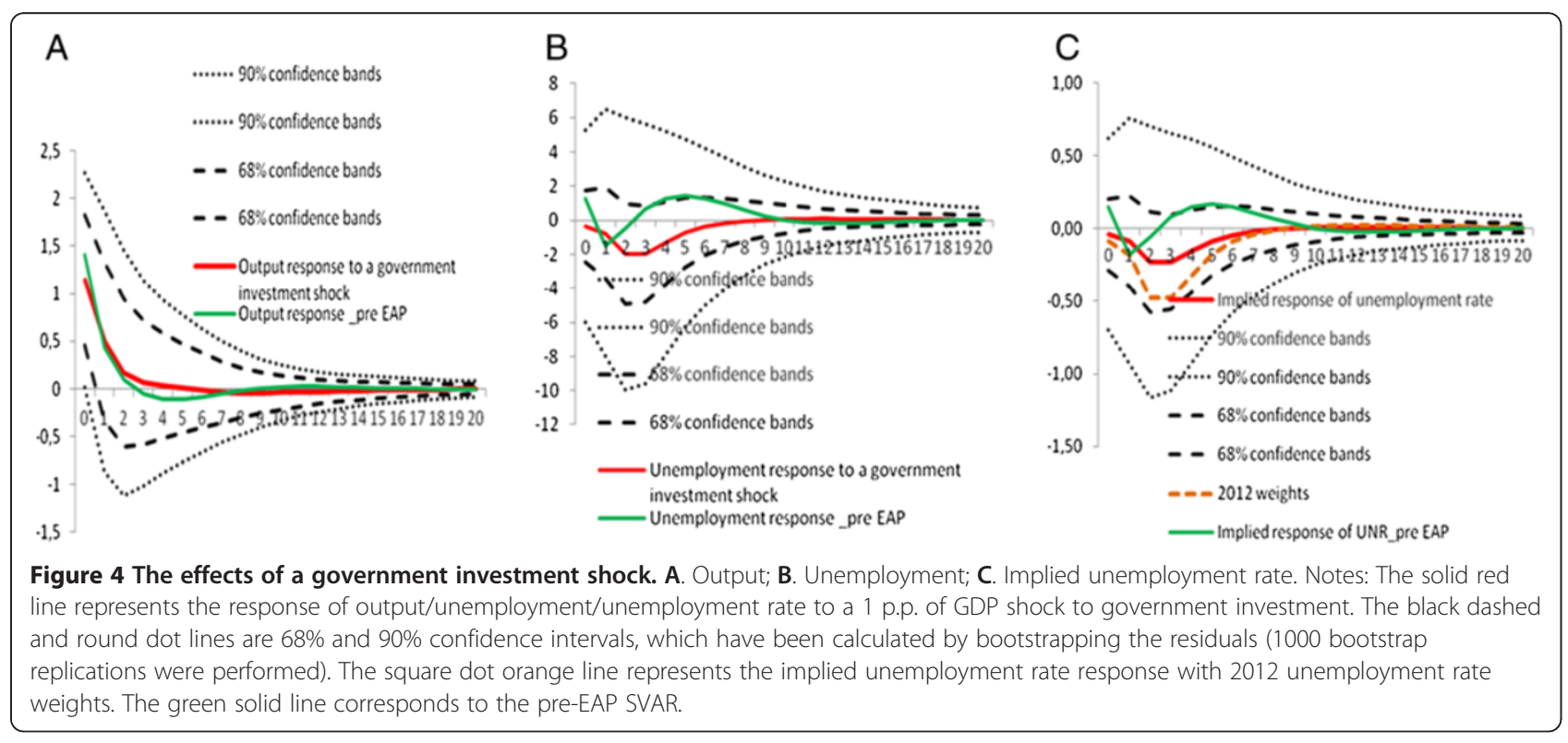




A
Figure $\mathbf{5}$ The effects of a government transfer shock. A. Output; B. Unemployment; C. Implied unemployment rate. Notes: The solid red line
represents the response of output/unemployment/unemployment rate to a 1 p.p. of GDP shock to government transfers. The black dashed and
round dot lines are 68\% and $90 \%$ confidence intervals, which have been calculated by bootstrapping the residuals (1000 bootstrap replications
were performed). The square dot orange line represents the implied unemployment rate response with 2012 unemployment rate weights. The
green solid line corresponds to the pre-EAP SVAR.




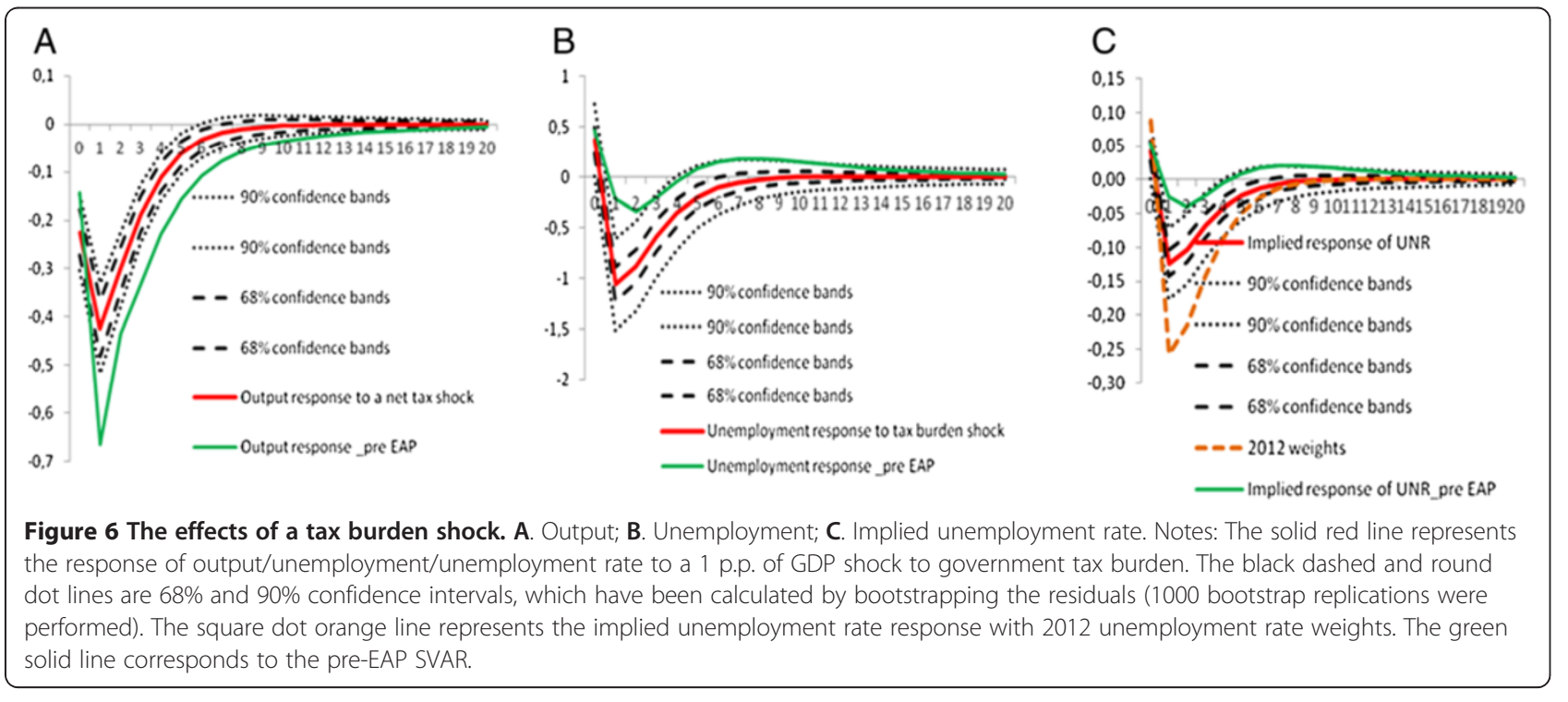




- Outputresponse to
direct taxes shock



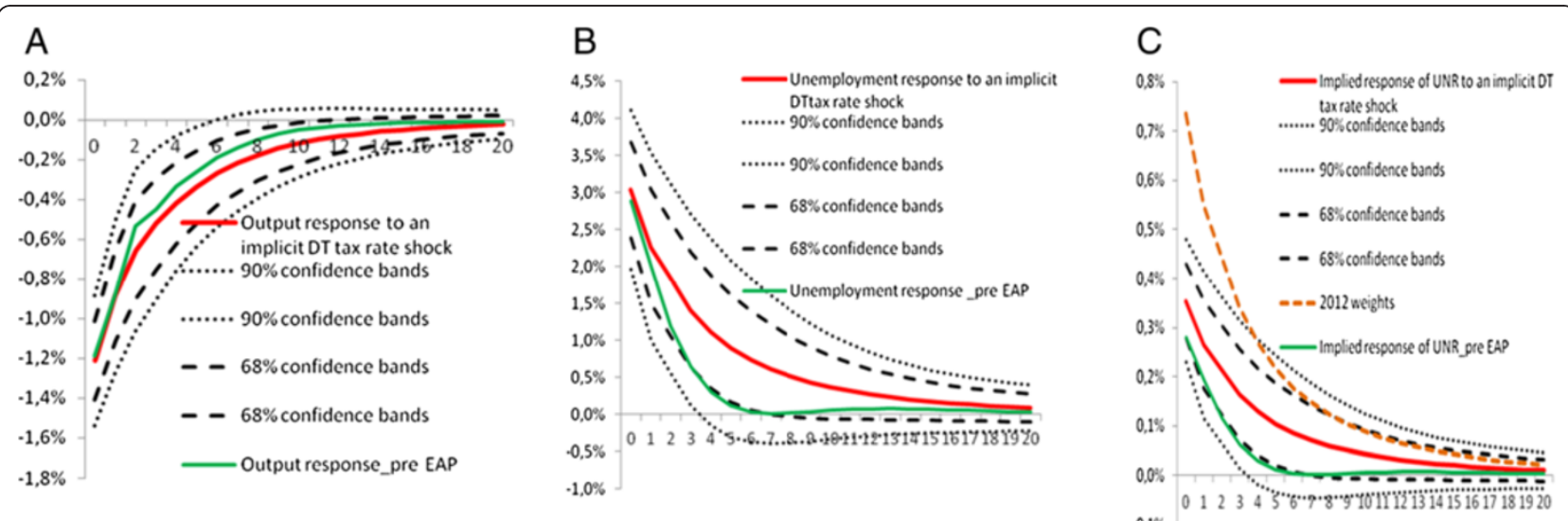

$0,1 \%$

Figure 8 The effects of an implicit direct tax rate shock. A. Output; B. Unemployment; C. Implied unemployment rate. Notes: The solid red line represents the response of output/unemployment/unemployment rate to a 1 p.p. shock to the implicit direct tax rate. The black dashed and round dot lines are 68\% and 90\% confidence intervals, which have been calculated by bootstrapping the residuals (1000 bootstrap replications were performed). The square dot orange line represents the implied unemployment rate response with 2012 unemployment rate weights. The green solid line corresponds to the pre-EAP SVAR. 


- Outputresponse to an indirect tax shock
Figure 9 The effects of an indirect tax shock. A. Output; B. Unemployment; C. Implied unemployment rate. Notes: The solid red line represents
the response of output/unemployment/unemployment rate to a 1 p.p. Of GDP shock to indirect taxes. The black dashed and round dot lines are
$68 \%$ and $90 \%$ confidence intervals, which have been calculated by bootstrapping the residuals (1000 bootstrap replications were performed). The
square dot orange line represents the implied unemployment rate response with 2012 unemployment rate weights. The green solid line
corresponds to the pre-EAP SVAR.



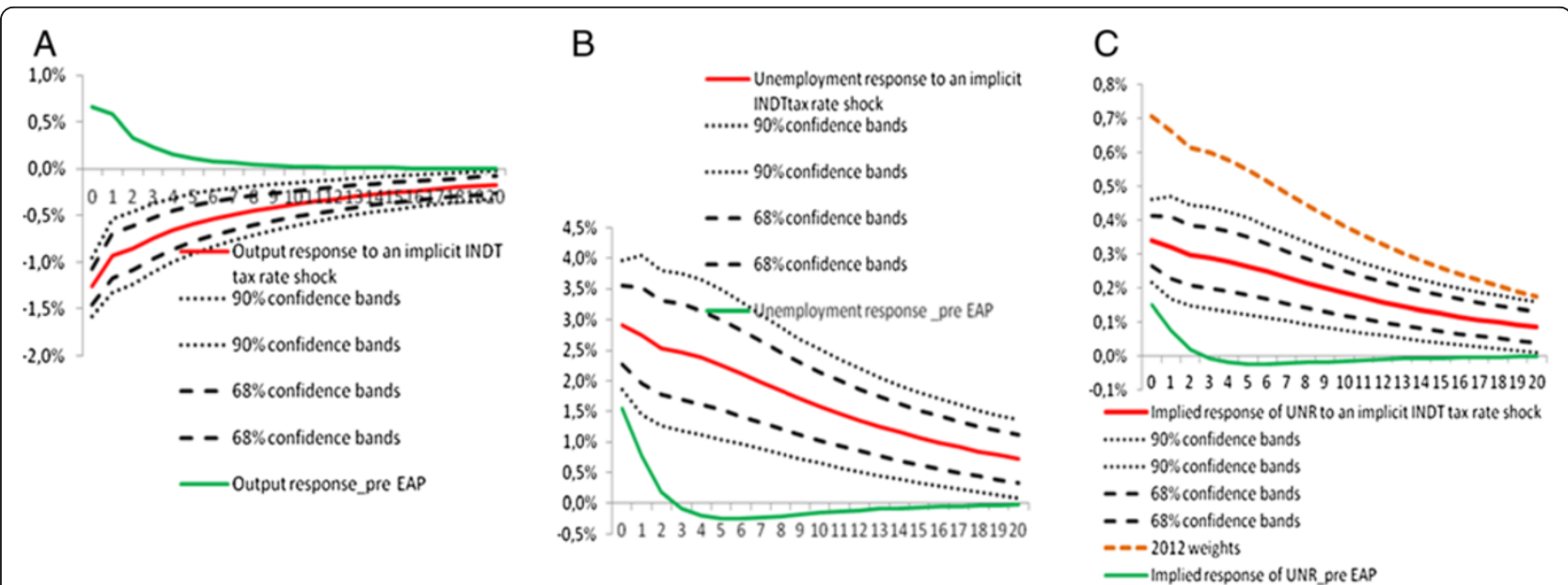

Figure 10 The effects of an implicit indirect tax rate shock. A. Output; B. Unemployment; C. Implied unemployment rate. Notes: The solid red line represents the response of output/unemployment/unemployment rate to a 1 p.p. shock to the implicit indirect tax rate. The black dashed and round dot lines are $68 \%$ and $90 \%$ confidence intervals, which have been calculated by bootstrapping the residuals (1000 bootstrap replications were performed). The square dot orange line represents the implied unemployment rate response with 2012 unemployment rate weights. The green solid line corresponds to the pre-EAP SVAR. 
the same analysis for a short time span running from 2000 till 2010 Q1, just before Greece lost marker access. The solid green line in Figures 1, 2, 3, 4, 5, 6, 7, 8, 9 and 10. represents the response profile of the variables of interest in the pre-EAP period.

Furthermore, when presenting the effects of fiscal policy on unemployment rate we consider the possibility that unemployment rate stabilizes at its currently high levels (before declining as assumed by EAP); i.e., despite the significant progress in labor market reforms (IMF 2013a; European Commission 2013c) we assume that it will take more time to reduce the unemployment rate. Hence, when constructing the implied unemployment rate responses we consider two possibilities: a) that the unemployment rate will return back to each sample average level (around 11.6\%) and b) that it will stabilize at its 2012 level $(24.3 \%)^{18}$. This allows us get a better sense of labor market effects of fiscal policy in the post crisis era.

In Tables 1, 2, 3, 4 and 5 we summarize some of the findings reported in Figures 1, 2, $3,4,5,6,7,8,9$ and 10. In Tables 1 and 3 we report the output and unemployment impact multipliers following government expenditure and revenue shocks, while in Tables 2 and 4 we report the cumulative multipliers. In Table 5 we report the estimated semi-elasticities following a 1 percentage point increase in the implicit direct and indirect tax rates. The impact multiplier is constructed as follows: The original impulse responses of the responding variable (e.g. output, unemployment) are divided by the impact response (at $t=0)$ of the government spending $(\operatorname{tax})$ variable expressed in percentage points of GDP. The cumulative multiplier is defines as follows: The cumulative e.g. GDP, multiplier at horizon $\mathrm{X}$ is computed as the cumulative percentage change in GDP after $\mathrm{X}$ quarters, divided by the cumulative change in government spending, expressed in percentage point of GDP, at the same horizon (see Monacelli et al. 2010).

\subsection{Government expenditure}

The solid red line in Figure 1A represents the response of output to a government purchases shock of 1 percentage point (p.p.) of GDP. The response of output is statistically significant for most of the time horizon considered. The impact response of output to a 1 p.p. of GDP shock in government purchases is estimated at 0.41 (see Table 1); it gradually declines to 0.17 two years after the shock. The cumulative output multiplier rises to 0.93 one year after the shock and approaches 1.28 two years after the shock (see Table 2). Overall, output responds in a quite persistent manner to a government purchases shock. Interestingly, the output impact response to a government purchases shock was much smaller in the pre-EAP period, i.e., around 0.14 p.p. In addition, it followed a quite different response profile, increasing to about 0.4 p.p. of GDP in quarter 1 before declining at a much faster pace 5 quarters after the shock.

Following a positive government purchases shock unemployment declines displaying an inverse hump-shaped profile as in Monacelli et al. (2010); see Figure 1B. The response is statistically significant for most of the time horizon considered based on the $68 \%$ confidence bands. Unemployment falls on impact by about $1.34 \%$ and by about $2 \%$ one year after the shock. When considering the smaller pre-EAP sub-sample we find a smaller impact effect around 1\%, and a much more pronounced negative response one year after the shock (about 3.6\%), in line also with the more pronounced output response shown in Figure 1A. However, when considering the full sample, the response 
Table 1 Estimated response mutlipliers of government spending components

\begin{tabular}{|c|c|c|c|c|c|c|c|c|c|c|c|c|c|c|c|}
\hline \multirow[b]{2}{*}{ Horizon } & \multicolumn{3}{|c|}{ Government purchases } & \multicolumn{3}{|c|}{ Government consumption } & \multicolumn{3}{|c|}{ Government investment } & \multicolumn{3}{|c|}{ Government wage bill } & \multicolumn{3}{|c|}{ Government transfer } \\
\hline & $\Delta Y / \Delta(G P)$ & $\Delta \mathrm{u} / \Delta(\mathrm{GP})$ & $\begin{array}{l}\Delta u / \Delta(G P) \\
(2012)\end{array}$ & $\Delta \mathrm{Y} / \Delta(\mathrm{GC})$ & $\Delta \mathrm{u} / \Delta(\mathrm{GC})$ & $\begin{array}{l}\Delta u / \Delta(G C) \\
(2012)\end{array}$ & $\Delta \mathrm{Y} / \Delta(\mathrm{Gl})$ & $\Delta \mathrm{u} / \Delta(\mathrm{Gl})$ & $\begin{array}{l}\Delta \mathrm{u} / \Delta(\mathrm{GI}) \\
(2012)\end{array}$ & $\Delta Y / \Delta(G W B)$ & $\Delta \mathrm{u} / \Delta(\mathrm{GWB})$ & $\begin{array}{l}\Delta \mathrm{u} / \Delta(\mathrm{GWB}) \\
(2012)\end{array}$ & $\Delta Y / \Delta(G T R)$ & $\Delta \mathrm{u} / \Delta(\mathrm{GTR})$ & $\begin{array}{l}\Delta \mathrm{u} / \Delta(\mathrm{GTR}) \\
(2012)\end{array}$ \\
\hline Impact & 0.41 & -0.15 & -0.32 & 0.29 & -0.17 & -0.34 & 1.14 & -0.04 & -0.09 & 0.92 & -0.30 & -0.62 & 0.41 & 0.04 & 0.08 \\
\hline 1st quarter & 0.25 & -0.14 & -0.28 & 0.29 & -0.15 & -0.31 & 0.50 & -0.09 & -0.18 & 0.97 & -0.29 & -0.59 & -0.07 & 0.13 & 0.28 \\
\hline 1 year & 0.23 & -0.20 & -0.42 & 0.20 & -0.23 & -0.48 & 0.03 & -0.16 & -0.32 & 0.49 & -0.31 & -0.65 & -0.02 & 0.00 & -0.01 \\
\hline 2 years & 0.17 & -0.09 & -0.19 & 0.06 & -0.06 & -0.13 & -0.04 & 0.00 & -0.01 & 0.23 & -0.16 & -0.33 & 0.00 & 0.00 & 0.00 \\
\hline
\end{tabular}

Notes: GP Government purchases, GC Government consumption, GI Government inestemnt, GWB Government wage bill, GTR Government transfers. 
Table 2 Estimated cumulative mutlipliers of government spending components

\begin{tabular}{|c|c|c|c|c|c|c|c|c|c|c|c|c|c|c|c|}
\hline \multirow[b]{2}{*}{ Horizon } & \multicolumn{3}{|c|}{ Government purchases } & \multicolumn{3}{|c|}{ Government consumption } & \multicolumn{3}{|c|}{ Government investment } & \multicolumn{3}{|c|}{ Government wage bill } & \multicolumn{3}{|c|}{ Government transfer } \\
\hline & $\Sigma \Delta Y / \Sigma \Delta G P$ & $\Sigma \Delta \mathrm{u} / \Sigma \Delta \mathrm{GP}$ & $\begin{array}{l}\Sigma \Delta \mathrm{u} / \Sigma \Delta \mathrm{GP} \\
(2012)\end{array}$ & $\Sigma \Delta Y / \Sigma \Delta G C$ & $\Sigma \Delta \mathrm{u} / \Sigma \Delta \mathrm{GC}$ & $\begin{array}{l}\Sigma \Delta \mathrm{u} / \Sigma \Delta \mathrm{GC} \\
(2012)\end{array}$ & $\Sigma \Delta Y / \Sigma \Delta G I$ & $\Sigma \Delta \mathrm{u} / \Sigma \Delta \mathrm{Gl}$ & $\begin{array}{l}\Sigma \Delta \mathrm{u} / \Sigma \Delta \mathrm{GI} \\
(2012)\end{array}$ & $\begin{array}{l}\Sigma \Delta Y / \\
\Sigma \Delta G W B\end{array}$ & $\begin{array}{l}\Sigma \Delta u / \\
\Sigma \Delta G W B\end{array}$ & $\begin{array}{l}\Sigma \Delta u / \Sigma \Delta G W B \\
(2012)\end{array}$ & $\begin{array}{l}\Sigma \Delta Y / \\
\Sigma \Delta N G T\end{array}$ & $\begin{array}{l}\Sigma \Delta \mathrm{u} / \\
\Sigma \Delta \mathrm{GTR}\end{array}$ & $\begin{array}{l}\Sigma \Delta \mathrm{u} / \Sigma \Delta \mathrm{GTR} \\
(2012)\end{array}$ \\
\hline Impact & 0.41 & -0.15 & -0.32 & 0.29 & -0.17 & -0.34 & 1.14 & -0.04 & -0.09 & 0.92 & -0.30 & -0.62 & 0.41 & 0.04 & 0.08 \\
\hline 1st quarter & 0.54 & -0.24 & -0.49 & 0.46 & -0.25 & -0.52 & 1.03 & -0.08 & -0.17 & 2.33 & -0.72 & -1.49 & 0.42 & 0.21 & 0.44 \\
\hline 1 year & 0.93 & -0.74 & -1.54 & 1.05 & -0.96 & -2.00 & 0.85 & -0.33 & -0.69 & 6.17 & -2.72 & -5.65 & 0.38 & 0.35 & 0.72 \\
\hline 2 years & 1.28 & -0.91 & -1.89 & 1.68 & -1.55 & -3.21 & 0.72 & -0.35 & -0.73 & 12.58 & -6.25 & -12.98 & 0.33 & 0.33 & 0.69 \\
\hline
\end{tabular}

Notes: GP Government purchases, GC Government consumption, GI Government inestemnt, GWB Government wage bill, GTR Government transfers. 
Table 3 Estimated response mutlipliers of tax components

\begin{tabular}{|c|c|c|c|c|c|c|c|c|c|}
\hline \multirow[b]{2}{*}{ Horizon } & \multicolumn{3}{|c|}{ Tax burden } & \multicolumn{3}{|c|}{ Direct taxes } & \multicolumn{3}{|c|}{ Indirect taxes } \\
\hline & $\begin{array}{l}\Delta Y / \\
\Delta(T X B)\end{array}$ & $\begin{array}{l}\Delta \mathrm{u} / \\
\Delta(\mathrm{TXB})\end{array}$ & $\begin{array}{l}\Delta \mathrm{u} / \Delta(\mathrm{TXB}) \\
(2012)\end{array}$ & $\begin{array}{l}\Delta Y / \\
\Delta(D T)\end{array}$ & $\begin{array}{l}\Delta \mathrm{u} / \\
\Delta(\mathrm{DT})\end{array}$ & $\begin{array}{l}\Delta u / \Delta(D T) \\
(2012)\end{array}$ & $\begin{array}{l}\Delta Y / \\
\Delta \text { (INDT) }\end{array}$ & $\begin{array}{l}\Delta \mathrm{u} / \\
\Delta(\text { INDT })\end{array}$ & $\begin{array}{l}\Delta \mathrm{u} / \Delta \text { (INDT) } \\
(2012)\end{array}$ \\
\hline Impact & -0.22 & 0.04 & 0.09 & -1.33 & 0.50 & 1.03 & -0.14 & 0.01 & 0.01 \\
\hline 1st quarter & -0.42 & -0.12 & -0.26 & -0.86 & 0.17 & 0.35 & -0.24 & -0.10 & -0.21 \\
\hline 1 year & -0.11 & -0.04 & -0.09 & -0.17 & -0.06 & -0.12 & -0.06 & -0.04 & -0.08 \\
\hline 2 years & -0.01 & 0.00 & -0.01 & 0.07 & -0.08 & -0.17 & 0.01 & -0.01 & -0.02 \\
\hline
\end{tabular}

Notes: TXB Tax burden, DT Direct taxes, INDT Indirect taxes.

of unemployment to a government purchases shock is much more persistent and pronounced after the $7^{\text {th }}$ quarter, as was also the case with the full sample output response.

The unemployment rate falls on impact by about 0.15 percentage (\%) points and by about 0.20 percentage points one year after the shock (Table 1 ). Turning to the cumulative multipliers, following a 1 p.p. of GDP shock in government purchases the unemployment rate falls by about 0.74 p.p. one year after the shock and by 0.91 p.p. two years after the shock (see Table 2). The implied response of unemployment rate is more pronounced when considering the pre-EAP period (green line in Figure 1C). The implied response of unemployment rate differs substantially if we use the 2012 unemployment data (orange square dot line in Figure 1C) instead of the sample average to construct the implied response of unemployment ${ }^{19}$. In this case the unemployment rate falls on impact by about 0.32 p.p., while the cumulative unemployment rate response is 1.54 p.p. and 1.89 p.p. one and two years after the shock, respectively ${ }^{20}$.

Overall, the findings indicate that, driven by the post EAP period, both output and unemployment responses to government purchases shocks have become more persistent ${ }^{21}$.

\subsubsection{Government spending sub-components}

The output response to a government consumption shock (Figure 2A) resembles the output response profile to a government purchases shock, but it is slightly less persistent. The impact response of output is 0.29 p.p. of GDP and the cumulative response reaches 1.68 p.p of GDP two years after the shock. In the pre-EAP period the output response profile followed a hump-shaped pattern having a negative impact response. The response of unemployment is slightly more pronounced compared to a government purchases shock in the first 1-2 years after the shock but then it declines at a much faster pace (Figures 2B-2C). The pre-EAP unemployment response is smaller on impact, but more pronounced until the $6-7^{\text {th }}$ quarter. Thereafter, it decays more rapidly. However, when considering only 2012 weights to construct the whole sample unemployment rate response we find an impact multiplier of -0.34 , with the response

Table 4 Estimated cumulative mutlipliers of tax components

\begin{tabular}{|c|c|c|c|c|c|c|c|c|c|}
\hline \multirow[b]{2}{*}{ Horizon } & \multicolumn{3}{|c|}{ Tax burden } & \multicolumn{3}{|c|}{ Direct taxes } & \multicolumn{3}{|c|}{ Indirect taxes } \\
\hline & $\begin{array}{l}\Sigma \Delta Y / \\
\Sigma \Delta T X B\end{array}$ & $\begin{array}{l}\Sigma \Delta u / \\
\Sigma \Delta T X B\end{array}$ & $\begin{array}{l}\Sigma \Delta \mathrm{u} / \Sigma \Delta \mathrm{TXB} \\
(2012)\end{array}$ & $\begin{array}{l}\Sigma \Delta Y / \\
\Sigma \Delta D T\end{array}$ & $\begin{array}{l}\Sigma \Delta u / \\
\Sigma \Delta D T\end{array}$ & $\begin{array}{l}\Sigma \Delta u / \Sigma \Delta D T \\
(2012)\end{array}$ & $\begin{array}{l}\Sigma \Delta Y / \\
\Sigma \Delta I N D T\end{array}$ & $\begin{array}{l}\Sigma \Delta u / \\
\Sigma \Delta I N D T\end{array}$ & $\begin{array}{l}\Sigma \Delta u / \Sigma \Delta I N D T \\
(2012)\end{array}$ \\
\hline Impact & -0.22 & 0.04 & 0.09 & -1.33 & 0.50 & 1.03 & -0.14 & 0.01 & 0.01 \\
\hline 1st quarter & -0.60 & -0.08 & -0.16 & -1.54 & 0.47 & 0.97 & -0.30 & -0.08 & -0.16 \\
\hline 1 year & -2.49 & -0.32 & -0.67 & -1.46 & 0.33 & 0.69 & -0.69 & -0.26 & -0.53 \\
\hline 2 years & -2.95 & -0.40 & -0.83 & -1.34 & 0.16 & 0.34 & -0.69 & -0.31 & -0.64 \\
\hline
\end{tabular}

Notes: TXB Tax burden, DT Direct taxes, INDT Indirect taxes. 
Table 5 Estimated semi-elasticities of tax components

\begin{tabular}{|c|c|c|c|c|c|c|}
\hline \multirow[b]{2}{*}{ Horizon } & \multirow[b]{2}{*}{$\begin{array}{l}\Delta Y / \\
\Delta(\text { ImplDT) }\end{array}$} & \multicolumn{2}{|c|}{ Implicit direct tax rate } & \multicolumn{3}{|c|}{ Implicit indirect tax rate } \\
\hline & & $\begin{array}{l}\Delta \mathrm{u} / \\
\Delta(\mathrm{ImplDT})\end{array}$ & $\begin{array}{l}\Delta u / \Delta(I m p \mid D) \\
(2012)\end{array}$ & $\begin{array}{l}\Delta Y / \\
\Delta(\text { ImplINDT) }\end{array}$ & $\begin{array}{l}\Delta \mathbf{u} / \\
\Delta(\text { ImplINDT })\end{array}$ & $\begin{array}{l}\Delta \mathrm{u} / \Delta(\text { ImplINDT) } \\
(2012)\end{array}$ \\
\hline Impact & $-1.21 \%$ & $0.35 \%$ & $0.74 \%$ & $-1.26 \%$ & $0.34 \%$ & $0.71 \%$ \\
\hline 1st quarter & $-0.89 \%$ & $0.26 \%$ & $0.55 \%$ & $-0.93 \%$ & $0.32 \%$ & $0.66 \%$ \\
\hline 1 year & $-0.42 \%$ & $0.13 \%$ & $0.27 \%$ & $-0.65 \%$ & $0.28 \%$ & $0.58 \%$ \\
\hline 2 years & $-0.18 \%$ & $0.06 \%$ & $0.12 \%$ & $-0.45 \%$ & $0.21 \%$ & $0.45 \%$ \\
\hline
\end{tabular}

Notes: ImpIDT Implicit direct tax rate, ImplINDT Implicit indirect tax rate.

rising to -0.49 p.p. of GDP one year after the shock (see Tables 1 and 2). The cumulative multiplier one and two years after the shock approaches -2.0 p.p. and -3.21 p.p. of GDP, respectively (a response much more pronounced compared to the government purchases case).

A government wage bill shock of 1 p.p. of GDP raises output on impact by about 0.92 p.p., and by 0.97 p.p. of GDP one quarter after the shock. Then it gradually returns to zero with a profile resembling to the government purchase response (Figure 3A); whereas the cumulative output response is much more pronounced (see Figure 3A and Tables 1 and 2). In case of a wage bill shock the negative responses of unemployment and unemployment rate are more sizeable and the peak response occurs earlier compared to government spending shocks (see Figures 3B-3C), i.e., unemployment declines by $2.5 \%$ and the unemployment rate falls by 0.30 p.p. on impact. The cumulative unemployment response reaches about -2.7 p.p. one year after the shock and -6.25 p.p. two years after the shock (see Tables 1 and 2). The pre-EAP response of unemployment is much more pronounced the first three quarters after the shock, but then it returns rapidly to zero. The effects are quite dramatic if we assume that the unemployment rate will stabilize around its 2012 value; i.e. the impact response of unemployment rate is -0.62 becoming -0.65 one year after the shock. The cumulative responses indicates rapidly rising unemployment rates in the event of cut in government wage bill.

Hence, contrary to other studies (Lane and Perotti 2003; Alesina et al. 2002) that have identified a non-Keynesian response of output in the case of a government wage bill shock due to the (indirect) labor cost channel, in our case we do find a strong Keynesian response of output. An increase in the government wage bill leads to a direct boost in domestic demand, which then expands output and reduces unemployment. This also reveals the important role that the government sector had acquired over the years in the workings of the Greek economy. This has worked through both higher wages and expansion of government employment ${ }^{22}$. As a result, cuts in the wage bill component (which are at the heart of the on-going fiscal consolidation effort) have dire consequences for demand and output.

The output response to a government investment shock is significant only for the first 1-2 quarters. The impact multiplier of output is estimated at 1.14 compared to 1.40 in the pre-EAP sub-sample (see Tables 1 and 2), implying that government investment cuts will have the most acute impact effects on output. However, in both cases the output responses rapidly go back to zero (Figure 4A). Unemployment declines following a government investment shock, but the response is not statistically significant (see Figure 4B-4C). 
Following a positive 1 p.p. of GDP government transfers shock output increases on impact by 0.41 p.p., however, thereafter the impulse response rapidly returns to zero (Figure 5A $)^{23}$. The short lived positive response of output and the positive response of unemployment in the first few quarters after the shock (afterwards it converges to zero) indicates the inefficient design of social spending in Greece, which have been highlighted by international organizations as being inadequate to cater social needs and to reduce poverty (OECD, 2011).

\subsubsection{Assessment}

Output and unemployment respond in a Keynesian manner to government spending shocks. The sizeable impact output and unemployment responses to a government purchases shock are driven by the EAP period (2010 Q2- present); a finding which is in line with Blanchard and Leigh (2013). The stronger output and unemployment impact response to government purchases shock in the whole sample case could be explained by the tightness of credit conditions in recent years. Recent studies have shown that fiscal policy has more pronounced effect in times of credit constraints (see Tagkalakis 2008; Aghion et al. 2009). Credit to the domestic sector has been shrinking in Greece since 2011 , i.e. by $-3.1 \%$ in $2011,-4.0 \%$ in 2012 and by $-3.7 \%$ (year-on-year) in May 2013. The deleveraging is projected to continue in 2013 and 2014 (IMF 2013a,b) ${ }^{24}$.

In addition, in a more liberalized labor market the effects of fiscal policy shocks could be more pronounced on impact, as it is easier to shed employment in times of declining demand. However, the rebalancing of the economy tends to be easier because resources move faster to the most productive use where there are new employment opportunities. In this case, the impact effect on unemployment and output following a fiscal policy shock will be higher in a liberalized compared to a more regulated market but then in the subsequent periods/quarters the rise of unemployment will be much less pronounced due to the absence of labor market rigidities which facilitate the direction of labor input to other more productive uses ${ }^{25}$.

This is exactly what we observe in Greece when we compare the unemployment responses in the pre-EAP and whole sample SVARs in quarters 1-7 following a government purchases shock (Figure 1$)^{26}$. The response of unemployment is less pronounced possibly due to the series of labor market reforms undertaken in recent years in the context of implementation of EAP. Nevertheless, after the $6^{\text {th }}-7^{\text {th }}$ quarter following the government purchases shock both output and unemployment respond in a more persistent and pronounced manner, which challenges the view that labor markets have started to bear fruit. Hence, although the effect on unemployment are more contained (excluding on impact) in the whole sample case, they tend to last longer than before, i. e., about 4 years.

However, if the unemployment rate stabilizes at high levels (2012 values 24.3\%) and does not decline rapidly to sample average values (11.6\%) or to the pre-EAP average (9.7\%) then the unemployment rate effects of government purchases shocks will be much more dramatic.

\subsection{Government revenue components}

The output response to a tax burden shock of 1 p.p. of GDP is shown in Figure 6A. Output declines on impact by about 0.22 p.p. of GDP; with the negative response 
reaching 0.42 p.p. of GDP one quarter after the shock (see Table 3). The output response declines fast afterwards returning to zero six to seven quarters after the shock; i.e., the output response to a tax burden shock is less persistent compared to the government purchases shock (Figure 1A). The cumulative multiplier reaches 2.5 p.p. and 2.95 p.p. one and two years after the shock (see Table 4). Interestingly, in case of the pre-EAP sample the output response is smaller on impact (0.14 p.p. of GDP) but then it becomes more pronounced (i.e. 0.67 p.p. one quarter after the shock) and more persistent ${ }^{27}$.

Both the unemployment and the unemployment rate increase on impact, by $0.36 \%$ and 0.04-0.09 p.p. respectively), but then decline crossing the zero line; the negative response remains significant until about the $6^{\text {th }}$ quarter after the shock (Figures 6B and $6 \mathrm{C})$.

\subsubsection{Government revenue sub-components}

A shock to direct taxes induces a negative output response which remains significant for about 6-7 quarters (based on the 68\% confidence bands - see Figure 7A). The impact response of output is estimated at -1.33 , while one years after the shock it approaches -0.17 . The cumulative output response reaches -1.5 one year after the shock and -1.3 two years after the shock (see Tables 3 and 4).

Both the unemployment and the unemployment rate increase on impact, by $4.3 \%$ and 0.50 p.p. (1.03 p.p. with 2012 weights), respectively. Both impulse responses return back to zero two to three quarters after the shock (Figure 7B-7C). The pre-EAP responses have the same profile, though the impact effects are more sizeable $(6.7 \%$ and about 0.80 p.p. of GDP respectively).

As a robustness check in Figure 8 we present the output and unemployment responses to an implicit direct tax rate shock. A 1 p.p. increase in the implicit direct tax rate lowers output on impact by about 1.2\% (see Table 5 for implicit tax rate semielasticities). The response of output is relatively more pronounced and persistent in the whole sample case (Figure 8A). Unemployment increases on impact by about $3.0 \%$ and the unemployment rate by about 0.34 p.p. (0.74 p.p. in case of 2012 weights); see Table 5. The responses of unemployment and unemployment rate are more sizable and persistent in the whole relative to the pre EAP sample (see Figures 8B-8C).

The output response to an indirect tax shock changes sign in the two cases considered, i.e., from a positive impact response in the pre-EAP sample we end up to a marginally negative response (of -0.14 p.p. of GDP) which returns rapidly to zero in the whole sample case (see Figure 9A). In addition, following an indirect tax shock both the unemployment and the unemployment rate increase marginally on impact and then contrary to what might be expected they both decline (see Figures 9B-9C).

As a robustness check in Figure 10 we present the output and unemployment responses to an implicit indirect tax rate shock. The output response is pretty much alike the one presented in Figure 9A; a 1 p.p. increase in the implicit indirect tax rate lowers output by about $1.26 \%$, while the response is positive in the pre-EAP sample. In addition, contrary to the evidence reported in Figures 9B-9C both the unemployment and the unemployment rate increase persistently. The impact responses are about $3.0 \%$ and 0.34 p.p. (and 0.71 p.p. using 2012 weights), respectively. The responses are more persistent compared to the pre-EAP sub-sample. 


\subsubsection{Assessment}

A pick up in tax burden, as well as in direct and indirect tax revenues does reduce output in a significant and persistent manner (to a lesser extend in case of indirect taxes), but in all cases the increase in unemployment is short lived. However, higher tax rates as captured by increasing implicit tax rates are associated with greater tax distortions which can be detrimental for growth, while at the same time inducing a more protracted unemployment response; a finding which is in line with Bassanini and Duval (2006a,b). Even though one would expect the post EAP unemployment responses to be less persistent (provided that labor market reforms have started to bear fruit) the evidence points to the opposite direction in case of increases in implicit tax rates.

\section{Summary and conclusions}

Motivated by recent developments this paper investigates the unemployment effects of fiscal policy changes in Greece in the period 2000-2012. It is a first attempt to analyse the impact of exogenous fiscal policy changes on unemployment in Greece based on the Blanchard and Perotti (2002) SVAR methodology.

Our findings indicate that an increase (cut) in government purchases and its subcomponents, i.e., government consumption, the government wage bill and government investment increase (lower) output and reduce (raise) unemployment and the unemployment rate. One year after the negative government purchase shock the unemployment rate increases by about 0.74 p.p. Two years after the shock the cumulative unemployment rate increase reaches about 0.91 p.p. The unemployment rate effects are more sizeable if we assume that the unemployment rate will stabilize at around its 2012 level (24.3\%). In this case the one and two year cumulative unemployment rate increase is 1.5 p.p. and 1.9 p.p. respectively. It is primarily government consumption, and in particular the wage bill component, that drives the output and unemployment responses. Higher government transfers have a short lived positive effect on output, but fail to reduce unemployment, possibly because they are inefficiently design and not well targeted (OECD 2011).

The output and unemployment responses to a government purchases shock are more sizable on impact in the whole sample vis-à-vis the pre-EAP period; a finding in line with Blanchard and Leigh (2013). However, for a period of one two years after the government purchases shock the response of unemployment is less pronounced in the whole sample case. Nevertheless, thereafter both output and unemployment responses become more persistent and pronounced. Hence, although the effects on unemployment are more contained (excluding on impact) in the whole sample case they tend to last longer than before, i.e., about 4 years. This implies that the series of labor market reforms that have been undertaken in the context of EAP aiming to liberalize the labor market might take more time to bear fruit.

Turning to the tax variables, increases in the tax burden and in direct and indirect taxes reduce output growth. The effects are more persistent in case of tax burden and direct taxes compared to indirect taxes. Unemployment increases after the tax shocks, but its positive effect is short lived. Both output and unemployment respond in a quite sizeable and persistent manner following tax hikes that involve increasing the implicit direct and indirect tax rates. The whole sample responses are driven by the EAP period 
developments. Higher implicit tax rates are associated with increased tax distortions that dampen output and lead to a protracted unemployment response.

Overall, the policy message that comes out of the analysis is that spending containment reduces output and increases unemployment. The effects can be quite sizeable and persistent in case of cuts in government consumption, government wage bill and to a lesser extent government investment. Whereas, reduced, but better targeted, government transfers will not necessarily be leading to higher unemployment. Tax hikes reduce output and increase unemployment, in particular those leading to higher implicit direct and indirect taxes.

According to European Commission (2013a) output growth reached a trough of $-7.1 \%$ in 2011, thereafter it is expected to gradually return to positive territory by 2014 (0.6\%). The unemployment rate is expected to reach its peak in 2013 (27\%) and will start decelerating from then on. Overall, this two year lag in the peak response of unemployment with respect to the trough of output growth seems reasonable. However, according to our findings in case of government purchases shocks the peak response of unemployment is about 1 year after the peak response of output (which occurs on impact). In case of tax shocks the peak unemployment response is on impact, but it has quite persistent response thereafter in case of implicit tax rate hikes.

The Greek government recently adopted the Medium Term Fiscal Strategy (MTFS) involving primarily wages and social benefits cuts of about 7.3\% of GDP for 2013-2014 with about 70\% of the measures impacting in 2013 (IMF, 2013a). Based this information and on the output and unemployment responses following spending and tax shocks found in this study and the delayed response of unemployment vis-à-vis output it would difficult for unemployment to start decelerating in 2014 (ceteris paribus) as foreseen in European Commission (2013a). Given that the majority of spending containment measures will impact on output growth immediately in 2013, the unemployment rate peak response should be expected in 2014 (ceteris paribus). Therefore, taking into account the macroeconomic effects of fiscal consolidation, the unemployment rate is more likely to start decelerating from 2015 onwards $^{28}$.

These findings imply that Greece is facing a important policy dilemma. The on-going fiscal consolidation is prerequisite for fiscal sustainability, however at the same time it has caused and will continue to cause significant adverse growth and labor market effects; i.e., spending cuts and direct tax hikes will continue dampening growth and increasing unemployment raising social tensions. Recent IMF work (IMF, 2012c), which is beyond the scope of the current study, suggests that better designed and targeted tax and expenditure policies (such as those included in the MTFS 2013-2016) could limit jobs losses (and could even boost employment) in a context of tight fiscal constraints. These policies involve boosting incentives to increase labor demand and supply. Unemployment could be reduced in the short run by lowering labor tax wedges, and expanding wage subsidies, especially for low-wage earners. Expanding active labor market programs could better match labor supply with labor demand, thereby reducing frictions. Measures to improved labor supply incentives, especially for women and older workers, will be beneficial for employment over the medium term.

Despite the significant progress in labor market reforms in recent years (IMF 2013a; European Commission 2013c) there is long way to go to improve the responsiveness of factors of production to economic conditions and to external shocks, in order to 
shorten the period of internal rebalancing. One reason relates to the, yet, inadequate progress in product market reforms which possibly delays the adjustment of factors of production, the entry of new firms and the rebalancing of economic activity (IMF, 2013a; European Commission, 2013c). Furthermore, policy makers could also take into account that it might take more time before structural reforms start to bear fruit in terms of reducing unemployment costs for society.

\section{Endnotes}

${ }^{1}$ The general government deficit was reduced from $15.6 \%$ of GDP in 2009 to $6.3 \%$ of GDP in 2012. The primary deficit improved by 8.2 percentage points (p.p.) of GDP from $10.5 \%$ in 2009 to $1.3 \%$ of GDP in 2012. Accounting for the cyclical effects, the improvement in the cyclically adjusted primary balances is much bigger i.e., about 15.2 p.p. of GDP. According to IMF (2013a) the cyclically adjusted primary balance is estimated to have reached a surplus of $2.2 \%$ of GDP in end 2012. This improvement in the cyclically adjusted primary balance in 2009-2012 has been supported by fiscal measures amounting to about $29 \%$ of GDP.

${ }^{2}$ From a $-2.0 \%$ growth rate in 2009 a trough point of $-4.0 \%$ was expected in 2010 . Thereafter, the growth rates projected were $-2.6 \%$ in 2011 and 1.1\% in 2012 (European Commission 2010).

${ }^{3}$ The unemployment rate was initially (European Commission 2010) expected to increase from $9.5 \%$ in 2009 , to $12.5 \%$ in 2010 , to $15.2 \%$ in 2012 , and to decline to $14.8 \%$ in 2013.

${ }^{4}$ We focus on the period that Greece was part of the euro area. Greece became part of the euro area on $1^{\text {st }}$ January 2001 but its euro entry was already decided in 2000, therefore we start out data set in 2000 because expectations for a euro area entry were already formed. Another reason to look at the post-2000 era relates to the fact it is only since 2000 that the statistical authorities of Greece have started the production and dissemination of quarterly non interpolated fiscal and economic activity data. It should be taken into account that all fiscal and economic activity data have been approved by Eurostat, i.e., the data used in the analysis are not subject to any statistical deficiencies (see Eurostat 2013).

${ }^{5} \mathrm{~A}$ additional information can be found in Additional file 1.

${ }^{6}$ However, the impact of labor taxes on unemployment comes also through various institutional features of the labor market, such as unionization and minimum wage settings.

${ }^{7}$ It should be pointed out that studies like Tagkalakis (2006), Pappa (2009), Monacelli et al. (2010) and others investigate the short run effects of fiscal policy on labor market variables via the identification of fiscal policy shocks. They usually follow either the SVAR approach of Blanchard and Perotti (2002), the Mountford and Uhlig (2009) sign restriction approach or the narrative approach of Ramey and Shapiro (1998) and Romer and Romer (2010). According to the SVAR approach of Blanchard and Perotti (2002) fiscal shocks are identified based the assumption that discretionary fiscal policy does not respond to output within the quarter, while also estimating elasticities of fiscal variables with respect to some macroeconomic variables in order to net out the automatic effects of fiscal policy. The Mountford and Uhlig (2009) approach identifies fiscal policy shocks by imposing sign restrictions on the way fiscal and macroeconomic variables 
would have to behave. In the so-called "narrative" approach of fiscal policy of Ramey and Shapiro (1998), Edelberg et al. (1999), Burnside, et al. (2004), Romer and Romer (2010) and Ramey (2011) fiscal policy shocks are identified based either on the military build up of the Korean and Vietnam wars (defence budget expansions) or on announced and implemented changes in tax legislation ("narrative" of Presidential speeches and Congressional records).

${ }^{8}$ Data were obtained from the International Financial Statistics of the IMF (IMF 2013b) and from the Economic Outlook of the OECD (2013a).

${ }^{9}$ Given that we are subtracting current government transfers from the tax variable we do account for possible correlation in different government expenditure components (i.e., o there is no need to add current transfers as a $5^{\text {th }}$ variable in the SVAR when we assess the effects of government spending/purchases shocks).

${ }^{10}$ To correct for seasonal patterns in the quarterly data we have applied the census X12 filter.

${ }^{11}$ The lag length was chosen based on non-autocorrelation and the information provided by relevant lag-length criteria (see Additional file 1).

${ }^{12}$ See Appendix A.1

${ }^{13}$ We have also considered the opposite case as Blanchard and Perotti (2002) and Favero and Giavazzi (2012), but the results are invariant to the ordering because the correlation between shocks is low enough and insignificant.

${ }^{14} \mathrm{Keep}$ in mind that in these specifications we subtract the current government transfers from current revenue so we have already accounted for their possible correlation with each expenditure component.

${ }^{15}$ The implicit direct tax rate is calculated as direct taxes divided by a proxy of its tax base which is the sum of compensation of employees and gross operating surplus (given that direct taxes impact on both individuals and corporations). The implicit indirect tax rate is calculated as indirect taxes divided by a proxy of its tax base, i.e. private consumption.

${ }^{16} \mathrm{We}$ have also considered two additional government revenue specifications: one where the variable of interest is social security contributions (SSC) and a second one with the implicit social security contributions tax rate. We proxy this with the ratio of social security contributions over compensation of employees. We examined both actual and total SSC (incorporating imputed SSC). The other fiscal variables in the SVAR were government purchases and tax revenue (direct plus indirect taxes). In all cases considered we did not find any statistically significant effect on output and unemployment following a shock in SSC (the implicit SSC tax rate). Output elasticities of SSC were obtained from Girouard and Andre (2005).

${ }^{17}$ See Appendix A.1

${ }^{18}$ The implied response of the unemployment rate is calculated as follows: the response of $\Delta \log$ of unemployment is multiplied with the average unemployment over the sample and divided by the average labor force over the sample. Alternatively, we use only the 2012 weights (orange square dot line). The 2000-2012 sample average is $11.6 \%$, the 2012 average is $24.3 \%$ and the pre-EAP sample average is $9.7 \%$.

${ }^{19}$ The implicit assumption is that the unemployment rate could stabilize in the years to come at higher average unemployment rate level (at around 24.3\% which is the 2012 value rather than around $11.6 \%$ which is the sample average). Alternatively, it could 
take long before returning to the $11.6 \%$ average (or the $9.7 \%$ pre-EAP average) given that according to European Commission (2013a) it is expected to remain at $26-27 \%$ in 2013-2014.

${ }^{20}$ The responses of the remaining variables in the SVAR are not shown here due to space limitation, but are presented in Additional file 1.

${ }^{21}$ As shown in the supplementary material appendix the response profile of government purchases to an own shock (normalized to 1 p.p. of GDP) displays the same pattern in the pre EAP and whole sample cases, i.e., the persistence of the government spending response is not responsible for the difference in the persistence of the output and unemployment responses in the pre-EAP and whole sample cases.

${ }^{22}$ In $2000-2001$ the government wage bill was about $10.4 \%$ of GDP, while in 2009 it expanded to $13.4 \%$ of GDP before declining to about $12.5 \%$ of GDP in 2012.

${ }^{23}$ Furceri and Zdzienicka (2012) report a positive short run growth effect from higher social spending in a panel of OECD countries.

${ }^{24}$ In addition output growth has been contracting in Greece since late 2008 till present. According to Auerbach and Gorodnichenko (2012) and Tagkalakis (2008) the effects of fiscal policy are more pronounced in periods of declining economic activity.

${ }^{25}$ Unfortunately there are not enough data points to examine separately the size and persistent of the output and unemployment response in the EAP period (from 2010 Q2 onwards) or to contact an analysis analogous to Auerbach and Gorodnichenko (2012). However, a back of the envelope exercise reveals the following: a 1 p.p. of GDP government purchases shock in the period 2000-2010 Q1 leads to an output multiplier of about 0.13 p.p. of GDP, while in the whole sample case running till 2012Q4 the output multiplier is 0.41 p.p. of GDP. Hence, in order for this whole sample effect to materialize (ceteris paribus) the fiscal multiplier in recent years, from 2010Q-2012Q4, should be expected to be about 1.5 p.p. of GDP. Similarly, unemployment effects $1.3 \%$ when considering the whole sample SVAR compared to $1 \%$ in the pre-EAP sub-sample. Hence, in order for this whole sample effect to materialize (ceteris paribus) the unemployment effect in recent years, from 2010Q-2012Q4, should be expected to be about $2.3 \%$. Hence, in order for the unemployment rate impact multiplier to be 0.15 (0.32 using 2012 weight) in the whole sample SVAR from 0.12 in the pre EAP sample, the unemployment rate multiplier should increase to as much 0.3 (0.6 using 2012 weights) in the period 2010Q22012 Q4.

${ }^{26}$ However, in case of government wage bill shock the unemployment response in the pre EAP sub-sample is more pronounced in the first few quarters but declines rapidly thereafter (Figure 3).

${ }^{27}$ As shown in the supplementary material appendix the response profile of tax burden to an own shock (normalized to 1 p.p. of GDP) displays the same pattern in the pre EAP and whole sample cases, i.e., the persistence of the tax burden response is not driving the difference in the persistence of the output and unemployment responses in the pre-EAP and whole sample cases. A back of the envelope exercise reveals the following: a 1 p.p. of GDP tax burden shock in the period 2000-2010 Q1 leads to an output multiplier of about -0.14 p.p. of GDP, while in the whole sample case running till 2012Q4 the output multiplier is -0.22 p.p. of GDP. Hence, in order for this whole sample effect to materialize (ceteris paribus) the tax burden multiplier of output in recent years, from 2010Q-2012Q4, should be expected to be about -0.53 p.p. of GDP. 
Contrary to government purchases case there are no substantial changes in the unemployment response to tax burden shock in the two cases.

${ }^{28}$ Of course, other policy initiatives could be used (structural reforms etc.) that could help contain the unemployment rate increase.

\section{Appendix}

\section{A.1 Government revenue and expenditure elasticities}

Girouard and Andre (2005) have estimated revenue and expenditure elasticities with respect to output gap for OECD countries. These elasticities are used to construct the cyclically adjusted balances - i.e., to clean the effect of the cycle from revenue, expenditure and primary and overall budget balances. The output elasticity of personal income tax is 1.80 , of corporate income tax is 1.08 , of social security contributions is 0.85 , and of indirect taxes is 1 . Using these and the sample averages of the shares of each tax category we set $\alpha_{\mathrm{ty}}=0.9$ in specification (2).

One drawback related to these elasticities obtained from Girouard and Andre (2005) is that they do not account for the fact that tax elasticities might vary over the business cycle. The European Commission is considering time-varying elasticities in order to complement its fiscal surveillance procedure. However these time invariant elasticities remain still a key element in fiscal surveillance procedures. Note that, a similar value for the elasticity of revenue with respect to output gap (0.9) is used by the European Commission for the calculation of the cyclically adjusted balance (see European Commission 2013b; Part III, Table III. A1.1).

In specification (2) we proxy the unemployment elasticity of revenues $\left(\alpha_{\mathrm{tU}}=-0.27\right)$ as follows: we multiply the output elasticity of revenues $\left(\alpha_{\text {ty }}=0.9\right)$ with the inverse of the elasticity of unemployment with respect to the output gap $\left(1 / \alpha_{\text {UYGAP }}\right)$, where $\alpha_{\text {UYGAP }}=-3.3$ the elasticity of unemployment with respect to the output gap is taken from Girouard and Andre (2005).

In case of specification (3) we set $\alpha_{\mathrm{GY}}=-0.17$ in case of government transfers. This is obtain as follows: we multiply the elasticity of unemployment with respect to the output gap (it is -3.3 from Girouard and Andre 2005) with the share of unemployment spending on government transfers which is around $5 \%$. This value is comparable with the output elasticity of government spending (sum of government purchases and government transfers) of -0.1 assumed by the European Commission. It is comparable because the only component of government spending that is automatically responding to economic activity is government transfers (i.e. the sample average is about $20 \%$ of GDP), while government purchases (sample average about $22.7 \%$ of GDP) does not respond contemporaneously to output changes. Given the abovementioned shares to GDP the value of $\alpha_{G Y}=-0.17$ is compatible with the assumptions adopted by the European Commission (2013b). Similarly to get $\alpha_{\mathrm{GU}}=0.05$, the unemployment elasticity of government transfers we assume that it corresponds to the share of unemployment spending to government transfers.

In the case of the SVAR specifications (3) the output elasticity of direct taxes is set to 1.40 and the output elasticity of indirect tax revenue is set to 1 based on the elasticities estimated by Girouard and Andre (2005). Using sample average we calculate the output elasticity of direct taxes as follows: share of personal income tax to direct taxes * elasticity of personal income tax to output gap + share of corporate income tax to direct 
taxes* elasticity of corporate income tax to output gap. The output gap elasticities of personal (1.8) and corporate (1.08) income taxes are taken from Girouard and Andre (2005). The respective shares to personal and corporate income tax revenue to direct taxes are about $2 / 3$ and $1 / 3$. The unemployment elasticity of indirect tax revenue is set to $\alpha_{\mathrm{tU}}=-0.30$ as follows: we multiply the unitary output elasticity of indirect tax revenue with the inverse of the elasticity of unemployment with respect to the output gap $\left(1 / \alpha_{\text {UYGAP }}\right)$, where $\alpha_{\text {UYGAP }}=-3.3$ according to Girouard and Andre (2005). The unemployment elasticity of direct taxes is set to $\alpha_{\mathrm{tU}}=-0.42$ as follows: we multiply the output elasticity of direct taxes (1.40) with the inverse of the elasticity of unemployment with respect to the output gap $\left(1 / \alpha_{\text {UYGAP }}\right)$, where $\alpha_{\text {UYGAP }}=-3.3$.

As regards the variables used as proxies for the implicit direct and indirect tax rates the output elasticities are set to 0.40 and 0 respectively for direct and indirect taxes. In case of direct taxes we know that $1 \%$ increase in output will raise direct taxes by $1.4 \%$. Assuming that the tax base (compensation of employees and gross operating surplus) increases one-to-one with output (in order to maintain a constant share in terms of output at around $89 \%$ in 2000-2012) we conclude that the implicit direct tax ratio will increase by about $0.40 \%$ for every $1 \%$ increase in output (given the progressivity of the tax system).

In case of the implicit indirect tax rate both the nominator, indirect taxes and the denominator, private consumption, are assumed to increase one-to-one with output following the findings of Girouard and Andre (2005) and assuming that the share of consumption in output has remained on average constant in the period 2000-2012 in Greece (at around 72\%).

Unemployment elasticities of implicit direct and indirect taxes are set to -0.15 and -0.08 respectively. As pointed out before the unemployment elasticities of direct and indirect taxes are -0.42 and -0.30 . The unemployment elasticities for the respective tax bases (compensation of employees and gross operating surplus and private consumption) are set to -0.27 and -0.22 respectively. They are calculated as follows: The elasticity of output gap with respect to unemployment is calculated as the inverse of the elasticity of unemployment with respect to the output gap $\left(1 / \alpha_{\text {UYGAP }}\right)$, where $\alpha_{\text {UYGAP }}=$ -3.3 from Girouard and Andre (2005). The elasticity of each respective tax base is calculated as the product of the elasticity of output gap with respect to unemployment with the share of each tax base to output. In case of direct taxes the sample average of the share of tax base to output is $89 \%$ and in case of indirect taxes it is $72 \%$. Subtracting the unemployment elasticities of direct $(-0.42)$ and indirect taxes $(-0.30)$ from the respective unemployment elasticities of their tax bases $(-0.27$ and -0.22 , respectively) we obtain the unemployment elasticities of implicit direct $(-0.15)$ and indirect $\operatorname{tax}(-0.08)$ rates.

\section{A.2 Data information}

The macroeconomic and fiscal data used in the analysis extent over the period 2000 to 2012 and were all taken from the International Financial Statistics of the International Monetary Fund (IMF, 2013b), the OECD Economic Outlook and the OECD Quarterly National Accounts (OECD 2013a,b). The house price data are from the Bank of Greece (2013).

To correct for seasonal patterns in the quarterly data we have applied the census X12 filter. The fiscal variables used are: the debt to GDP ratio, government purchases 
(government consumption plus government investment), government wage bill (compensation of employees), current government transfers, current revenue, net taxes (which equals current revenue minus current transfers) direct taxes, indirect taxes, tax burden, social security contributions (actual and total, i.e. including imputed). The government spending and revenue variables were first expressed in logarithmic terms $(\ln )$, next we transformed them in differences $(\Delta \ln )$ from $t$ to $t-4$ : real government spending, real government consumption spending, real government gross fixed capital formation, real net government transfers, real government compensation of employees, real net taxes, real tax burden, real direct and indirect taxes. Government spending and revenue variables were expressed in real terms after subtracting the log of the GDP deflator. For example in case of real government purchases we have $\Delta[\ln$ (government spending)-ln(GDP deflator)]. The implicit direct tax rate is the ratio of direct taxes to the sum of compensation of employees and gross operating surplus. The implicit indirect tax rate is the ratio of indirect taxes to private consumption. In the SVAR we use the percentage change from $t$ to $t-4$.

We examine the effect of the fiscal variables on the percentage change of unemployment $\Delta[\ln ($ number of unemployed) $]$ and the the growth rate of real GDP $\Delta[\ln (\mathrm{GDP})-\ln$ (GDP deflator)]. In addition we use also use labor force participation. The EAP dummy variable takes value 1 from 2010 Q2 till 2012 Q4.

\section{Additional file}

Additional file 1: Supplementary material appendix for “Unemployment effects of fiscal policy: recent

evidence from Greece". Diagnostic tests and additional impulse responses.

Competing interests

The IZA Journal of European Labor Studies is committed to the IZA Guiding Principles of Research Integrity. The author declares that he has observed these principles.

\section{Acknowledgements}

I would like to thank the Editor Alan Barrett and the reviewers of IZA Journal of European Labor Studies. The views expressed in the paper are mine and do not necessarily reflect those of the Bank of Greece. All remaining errors are mine.

Responsible editor: Alan Barrett

Received: 15 May 2013 Accepted: 15 August 2013

Published: 20 Sep 2013

\section{References}

Aghion D, Hemous D, Kharroubi E (2009) Credit constraints, cyclical fiscal policy and industry growth. In: NBER Working Paper No. 15119

Alesina A, Ardagna R, Perotti R, Schiantarelli F (2002) Fiscal policy, profits, and investment. Am Econ Rev 92:571-589 Ardagna S (2007) Fiscal policy in unionized labor markets. J Econ Dyn Con 31:1498-1534

Auerbach A, Gorodnichenko Y (2012) Measuring the Output Responses to Fiscal Policy. Am Econ J: Econ Pol 4:1-27

Bank of Greece (2013) Bulletin of Conjuctural Indicators, 150, May-June

Bassanini A, Duval R (2006a) The determinants of unemployment across OECD countries: Reassessing the role of policies and institutions. OECD Economic Studies, No. 42

Bassanini A, Duval R (2006b) Employment Patterns in OECD Countries: Reassessing the Role of Policies and Institutions. In: OECD Working Paper No. 486

Blanchard O, Leigh D (2013) Growth forecast errors and fiscal multipliers. In: IMF, Working Papers, No.1

Blanchard O, Perotti R (2002) An empirical characterization of the dynamic effects of government spending and taxes on output. Quar J Econ 117:1329-1368

Burnside C, Eichenbaum M, Fischer J (2004) Fiscal shocks and their consequences. J Econ Th 115:89-117

Cavallo M (2005) Government employment and the dynamic effects of fiscal policy shocks. In: Federal Reserve Bank of San Francisco, Working Paper No.16

Edelberg W, Eichenbaum M, Fischer J (1999) Understanding the effects of a shock to government purchases. R Econ Dyn 2:166-206

Elstat (2013) Press release, labor Force Survey: May. 8 August., Available at: http://www.statistics.gr/portal/page/portal/ ESYE/BUCKET/A0101/PressReleases/A0101_SJO02_DT_MM_05_2013_01_F_EN.pdf 
European Commission (2010) The Economic Adjustment Programme for Greece, Occasional Paper No. 61, May European Commission (2012) Second Economic Adjustment Programme for Greece, First Review - December, Occasional Papers No 123

European Commission (2013a) Economic Forecasts., Spring 2013

European Commission (2013b) Report on Public Finances in EMU. European Econ 4:145

European Commission (2013c) Second Economic Adjustment Programme for Greece - Third Review: July.

In: Occasional Papers, No.159

Eurostat (2013) News Release, Provision of deficit and debt data for 2012 - first notification, No 64/2013, 22 April 2013. Available at: http://europa.eu/rapid/press-release_STAT-13-64_en.htm

Fatas A, Mihov I (2001) The effects of fiscal policy on consumption and employment: theory and evidence. In: CEPR, Discussion Paper, No. 2760

Favero C, Giavazzi F (2007) Debt and the effects of fiscal policy. In: NBER, Working Paper No 12822

Favero C, Giavazzi F (2012) Measuring tax multipliers: The narrative method in fiscal VARs. Am Econ J: Econ Pol 4:69-94

Finn MG (1998) Cyclical effects of government's employment and goods purchases. Int Econ Rev 39:645-657

Furceri D, Zdzienicka A (2012) The effects of social spending on economic activity: Empirical evidence from a panel of OECD countries. Fiscal Studies 39(1):129-152

Gali L, Lopez-Salido JD, Valles J (2007) Understanding the effects of government spending on consumption. J Eur Econ Ass 5:227-270

Girouard N, Andre C (2005) Measuring cyclically-adjusted budget balances for OECD countries. In: OECD Working Papers, No. 434

IMF (2010) Greece: Staff report on request for a Stand-by Arrangement. In: IMF, Country Report No.10/110

IMF (2012a) Greece: Request for Extended Arrangement Under the Extended Fund Facility. In: IMF Country Report No. $12 / 57$

IMF (2012b) World Economic Outlook. Autumn, IMF, Washington

IMF (2012c) Fiscal Policy and Employment in Advanced and Emerging Economies. In: IMF Policy Paper, 15 June

IMF (2013a) Fourth review under the extended arrangement under the extended fund facility, request for waiver if applicability, modification of performance criteria, and rephrasing of access. In: IMF Country Report, No. 13/241 IMF (2013b) International Financial Statistics. IMF, Washington

Lane P, Perotti R (2003) The importance of composition of fiscal policy: evidence from exchange rate regimes. J Pub Econ 87:2253-2279

Monacelli T, Perotti R, Trigari A (2010) Unemployment fiscal multipliers. J Mon Econ 57:531-553

Mountford A, Uhlig H (2009) What are the effects of fiscal policy shocks? J App Econom 24:960-992

OECD (2011) Economic Surveys: Greece. OECD, Paris

OECD (2013a) Economic Outlook, No 91. OECD, Paris

OECD (2013b) Quarterly National Accounts database. OECD, Paris

Pappa E (2009) The effects of fiscal shocks on employment and the real wage. Int Econ Rev 50:217-244

Ramey V (2011) Identifying Government Spending Shocks: It's all in the Timing. Quar J Econ 126:1-50

Ramey V, Shapiro M (1998) Costly capital reallocation and the effects of government spending. Carn Roch Conf S Pub Pol 48:145-194

Romer CD, Romer DH (2010) The macroeconomic effects of tax changes: estimates based on a new measure of fiscal shocks. Am Econ Rev 100:763-801

Tagkalakis A (2006) The effects of macroeconomic policy shocks on the UK labor market. Int J Fin Econ 11:229-244

Tagkalakis A (2008) The Effects of Fiscal Policy on Consumption in Recessions and Expansions. J Pub Econ 92:1486-1508

10.1186/2193-9012-2-11

Cite this article as: Tagkalakis: The unemployment effects of fiscal policy: recent evidence from Greece. IZA

Journal of European Labor Studies 2013, 2:11

\section{Submit your manuscript to a SpringerOpen ${ }^{\circ}$ journal and benefit from:}

- Convenient online submission

- Rigorous peer review

- Immediate publication on acceptance

- Open access: articles freely available online

- High visibility within the field

Retaining the copyright to your article

Submit your next manuscript at $\gg$ springeropen.com 